\title{
THE DESTRUCTIVE MEXICAN BOOK BEETLE COMES TO BOSTON ${ }^{1}$
}

\section{By Raymond L. TAYLOR.}

Since so many of the most destructive insect pests of the United States are of foreign origin, and also, since so many of these undesirable immigrants have made inconspicuous entrances into the country on nursery stock, food stuffs, and other merchandise, any record of an exotic, which is destructive, and which has entered the country, should be of wide interest. Undetected, the Mexican book beetle definitely invaded the Port of Boston recently.

On Dec. 12, 1927, attention was called to the condition of a large shipment of books which had been received by N. J. Bartlett and Co., a Boston firm of book sellers. Help in the matter was asked and the damaged stock was inspected. The shipment comprised 29 sizable packing cases and represented the entire library, of fully 8000 volumes, of the late William T. Brigham, Director of the Bernice Pauahi Bishop Museum, Honolulu, Hawaii. Dr. Brigham was a noted bibliophile and his collection, which embraced much on ethnology and natural history and contained many rare editions, was conservatively valued at over $\$ 25,000$. At the death of Dr. Brigham, the books, presumably in perfect condition at that time, were packed in substantial wooden cases and stored in a warehouse in Honolulu for several years. Recently, they were purchased by the book concern mentioned and delivered in Boston in early December, 1927. When the books were unpacked, although the newspaper wrappings showed no evidences of injury, there was scarcely one of the collection not riddled by larval galleries and exit holes. Some of the books had only one or two borings, while others were so completely riddled that some pages were virtually consumed in their entirety and the remainder illegible. The majority, however, suffered severe injury to the bindings but were legible in spite

${ }^{1}$ Contributions from the Entomological Laboratory of the Bussey Institution, Harvard University. No. 290. 
of eleanly cut, circular holes, 1.5 to $2.3 \mathrm{~mm}$. and oblique, larger holes, all of which extended from part way to all the way through the book. The work was confined to the covers in many other cases and cleanly cut, circular holes of about $2.3 \mathrm{~mm}$. were very common in the backs. It was significant that old volumes with hand-made paper had their pages well perforated, while in recent books with clay-filled, chemical-laden paper, the injury was restricted to the binding. Also of significance, was. the fact that some of the books, which were damp and marked by a brown mold, were comparatively immune to severe damage. The galleries in the covers were irregular, often appeared to radiate from a common center, and, in general, resembled to some extent, Scolytid work in wood. There was remarkably little frass and the insects which caused the destruction were not readily visible. Indeed, this latter point was a mystifying feature of the problem. Dr. Brigham had had the reputation of taking excellent care of his library and the condition of his books was well rated in collectors' lists. Since, by this presumption, the extensive damage had occurred in the two to three years the boxes had been in storage and in transit, there should have been ample insect remains. To the contrary, there was an almost complete absence of these and a great scarcity of living larvæ and adults. The probable solution of this, however, was found and will be mentioned later. It should be evident from the foregoing that these book injuries were much more considerable than might be expected of any common book insect, of which there are, relatively, but a few known.

A preliminary search for the cause of this destruction, after an examination of at least fifty books, at length yielded three living larvæ and the intact bodies of two adult beetles, either dormant or dead. Mr. C. A. Frost kindly identified the coleopteron as a species of Catorama, family Anobiidæ. A review of the literature inspired the conclusion that this insect was, very probably, either Catorama mexicana or C. herbarium, and, at the same time, raised the interesting question, whether or not these two species might not be synonymous.

Catorama (or Cathorama) herbarium, in the literature, is 
usually ascribed to Gorham, but in Gorham's own book ${ }^{1}$, where it is described, he ascribes it to "Chevrolat, the Salle Collection, Habitat Mexico, Cordova (Sallé)." This species seems widespread throughout tropical America, and is reported as injurious to books, leather goods, upholstery, furniture, woods, etc. in Brazil, Grenada, Barbados, St. Vincent, and other West Indian Islands. It is considered much more destructive than any other book pest.

Catorama mexicana, which is listed in the Fauna Hawaiiensis and there ascribed to Chevrolat, has been reported a number of times as highly injurious to books and leather goods, has also been found in tamarind bark and has been bred out of velvet bean seeds. It seems distributed throughout the Hawaiian Islands.

Since this species, C. mexicana, is not listed in Junk's Coleopterorum Catalogus (1912) nor to be found elsewhere, there remains the decided possibility that an error has been made and that these two names are synonymous. An error in transcription, once made, might easily be perpetuated indefinitely, or until the genus was revised. The common name, Mexican book beetle, has been given to $C$. mexicana by a committee of the Hawaiian Entomological Society and this common name would be equally applicable in every way to $C$. herbarium.

A brief description of the insect found may not be amiss. The larva, about $3.5 \mathrm{~mm}$. in length, is a light grayish-cream colored little grub, somewhat thickly covered throughout, including the head, with fine, rather long, yellow hairs. The head is unicolorous with the body and not heavily chitinized except for the mouthparts and surrounding parts. These latter parts are light brown to darker, and the mandibles are tipped with black. The adult is a typical Catorama, a reddish-brown, ovoid-rectangular beetle about $3 \mathrm{~mm}$. in length. The anterior portion of the elytra and dorsum of the head are smooth and polished; the cheeks and the remainder of the elytra, as well as the ventral parts, are covered with a fine, light yellow pilosity.

In regard to the life history of Catorama herbarium, de Faria says that the eggs are laid on the bindings or leaf-edges of books.

${ }^{1}$ Biologia Centrali-Americana, Vol. 3, Part 2, p. 207. 
The eggs hatch in 5-6 days (in Brazil) and the young larvæ seek the paste of the bindings at first, but when they grow stronger, they attack the bindings themselves and feed until ready to pupate. The larvæ then tend to return to the external surface, which, in the case of books on library shelves, is the back bindings of the volumes. They increase the size of their mines and cover them with roofs of excreta and paper. The adults emerge through cleanly cut holes, thus the characteristic perforations in the backs of books are the exit holes. These perforations may be re-entered for the purpose of oviposition, although the act itself was never observed. De Faria adds that these beetles are nocturnal in habit in that, in hot weather, they may issue from the books at night and go to the windows of the room containing the library. In Sao Paulo, Brazil, the breeding season seems to be from October to December but during these months all stages of Catorama may be observed. The observations made in Boston on the habits of this destructive "book worm" follow.

Since the beetle is indigenous to the tropics, any life cycle in Massachusetts would, without doubt, be different from its cycle under tropical conditions, if, indeed, the species could persist here. It seems very probable that the fluctuations in humidity and especially the temperature changes of the seasons, so different from the climate of Hawaii, for example, would render impossible continued breeding of the insect in New England. A life cycle of insects raised in a greenhouse might be indicative if a humid climate of the correct sort could be approximated. It is exceedingly interesting, however, that, in spite of the time of year, an appreciable number of Catorama larvæ survived the conditions of transportation from Honolulu to Boston and that, since their arrival in early December, 1927, at room temperatures of from 40 to $65 \mathrm{deg}$. F., both in the book store and in the laboratory, they have shown no abatement of activity.

From this fact, there arises at once the serious possibility of the destruction of books in libraries which are heated in winter, should this insect be introduced. It seems improbable that books kept in well lit situations and in active circulation would be infested, nor does modern paper appear to be the ideal diet of 
the beetle larva, yet, with little used books, which are kept undisturbed in darkness, or with rare books of leather and handmade paper, there remains the possibility of an approximation here of the extensive injury caused in tropic libraries.

Three living larvæ and two adults, either dormant or dead, with hand-made paper for food, were placed in a glass vial which was subsequently corked. The vial was then placed in a desk drawer. Observations were made from time to time and they yielded several interesting results. A few days after these insects were confined as described above, it was noted that there were but two larvæ. A careful examination revealed a few particles of the other larva, which had evidently. been eaten by the surviving two. Unfortunately, it can not be stated whether or not the larva was killed by its companions or died from some other cause before its body was used for food. It was noted, at the same time, that these two larvæ had begun to consume the adult beetles as well. During a period of a week, the interiors of the two bodies were exhausted and thereafter the external, chitinized portions were broken into small fragments. It was impossible to ascertain whether or not these bits of the chitinized parts were actually eaten, but they were finally reduced, on the whole, to rather small particles. When the larvæ were finished with the remains of the adults, they both ate into the cork stopper. One larva, which mined on the surface, produced a furrow $11 \mathrm{~mm}$. long and about as wide as its body, or $1 \mathrm{~mm}$., while the other commenced a mine obliquely leading into the heart of the cork. After an absence of observation for ten days, it was found that but one larva was present. The inference is that this suvivor had eaten the other. This remaining larva continued to mine into the cork for a depth of $9 \mathrm{~mm}$. and then turned about and widened the mouth of the boring. This total activity took three weeks time after which, the grub crawled out upon the handmade paper and seemed as vigorous as ever although it had been bottled over five weeks. It is worthy of mention that the handmade paper was not eaten, and that protein and cork were preferred, apparently.

The cannibalistic habit of the larvæ, if at all general, would adequately account for the surprisingly few insects found in the 
books examined, in proportion to the extensive mines, and with a consideration of the probable elapsed time of two to three years. No other explanation was conceived that seemed to fit all the facts as well.

In view of the persisting activity of this Catorama beetle at room temperatures, since further examination of other volumes at the book store continued to show living larvæ, and with an estimation of the chance of this pest spreading to uninfested volumes under the same roof and, perhaps, even gaining a foothold in the many heated libraries in Metropolitan Boston, it was agreed that a thorough program of fumigation with carbon bisulphide should be carried out. In spite of the remote contingency of a spread of this exotic pest to other libraries, adequate control measures were obviously justified. It would seem a safe rule, that, in general, any immigrant insect with destructive proclivities should be regarded as dangerous, and treated as such, at least, until all of its habits are known and its potentialities duly measured.

Abstract.

A tropical Anobiid, Catorama sp., either C. mexicana, the Mexican book beetle of the Hawaiians, or C. herbarium of the West Indies (if they are not synonymous, as they may be), inflicted severe damage to a large shipment of books from Honolulu to Boston. Larvæ have been active and have fed for at least seven weeks in Massachusetts at room temperatures, and the possibility of infestation of heated libraries throughout the city is advanced as adequate justification for a thorough carbon bisulphide treatment of the infested stock. In general, any imported noxious insect should be treated as a menace, at least until all of its habits are known and its potentialities measured.

\section{Bibliography.}

Dash, J. S. Cat(h)orama herbarium. In Rept. of Ass't. Supt. of Agr. on the Entomological and Mycological Work carried out during the Season under Review. Rept. Dept. Agr. for 1916-1917, Barbados; pp. 56-60 (1917). 
de Faria, D. Catorama herbarium. In Os Inimigos dos nossos Livros. Servico Sanit. do Estado de Sao Paulo, S. Paulo; N. S. No. 4; pp. 1-40, 5 pl. (1919).

Fullawry, D. T. Catormaa mexicana. In Rept. of the Entomologist. Hawaiiian Stn. Rept. 1911; pp. 17-24 (1912).

Gorham, H. S. Catorama herbarium. In Biologia CentraliAmericana, Vol. III, Part 2, 1880-1886, p. 207 (1883).

Gorham, H. S. Catorama herbarium. In On the Serricorn Coleoptera of St. Vincent, Grenada, and the Grenadines. Proc. Zool. Soc. London 1898; p. 325 (1899).

Hawaiian Entomological Society. Catorama mexicana. In Proc. Hawaiian Ent. Soc., Vol. III, No. 4; p. 281 (1917).

Kotinsky, J. Catorama mexicana. A New Book and Leather Pest. Hawaiian Forester and Agr., Vol. 3, No. 4; pp. 117118 (1906).

Leng, Charles W. and Mutchler, Andrew J. Catorama herbarium. In A Preliminary List of Coleoptera of the West Indies as Recorded to Jan. 1, 1914; p. 435 (1914).

Perkins, R. C. L., Scott, Hugh, and Sharp, D. Catorama mexicana. In Fauna Hawaiiensis, Vol. III, Part VI, Coleoptera IV; p. 614 (1910).

Pic, M. Catorama herbarium. In Junk's Coleopterorum Catalogus, Part 48 (Anobiidæ); pp. 68-69 (1912).

Reinick, William R. Catorama mexicana. In Insects Destructive to Books. Am. Jour. Pharmacy, Vol. 83, No. 11; pp. 503-515 (1911).

Swezey, O. H. Catorama mexicana. In Maui Insect Notes. Proc. Hawaiian Ent. Soc., Vol. IV, No. 1; p. 3 (1919).

Timberlake, P. H. Catorama mexicana. In A Record of Introduced and Immigrant Chalcid Flies of the Hawaiian Islands. Proc. Hawaiian Ent. Soc., Vol. V, No. 3; p. 422 (1924).

Timberlake, P. H., Ehrhorn, E. M., and Swezey, O. H. Catorama mexicana. In Proc. Hawaiian Ent. Soc., Vol. IV, No. 3, p. 608 (1921). 

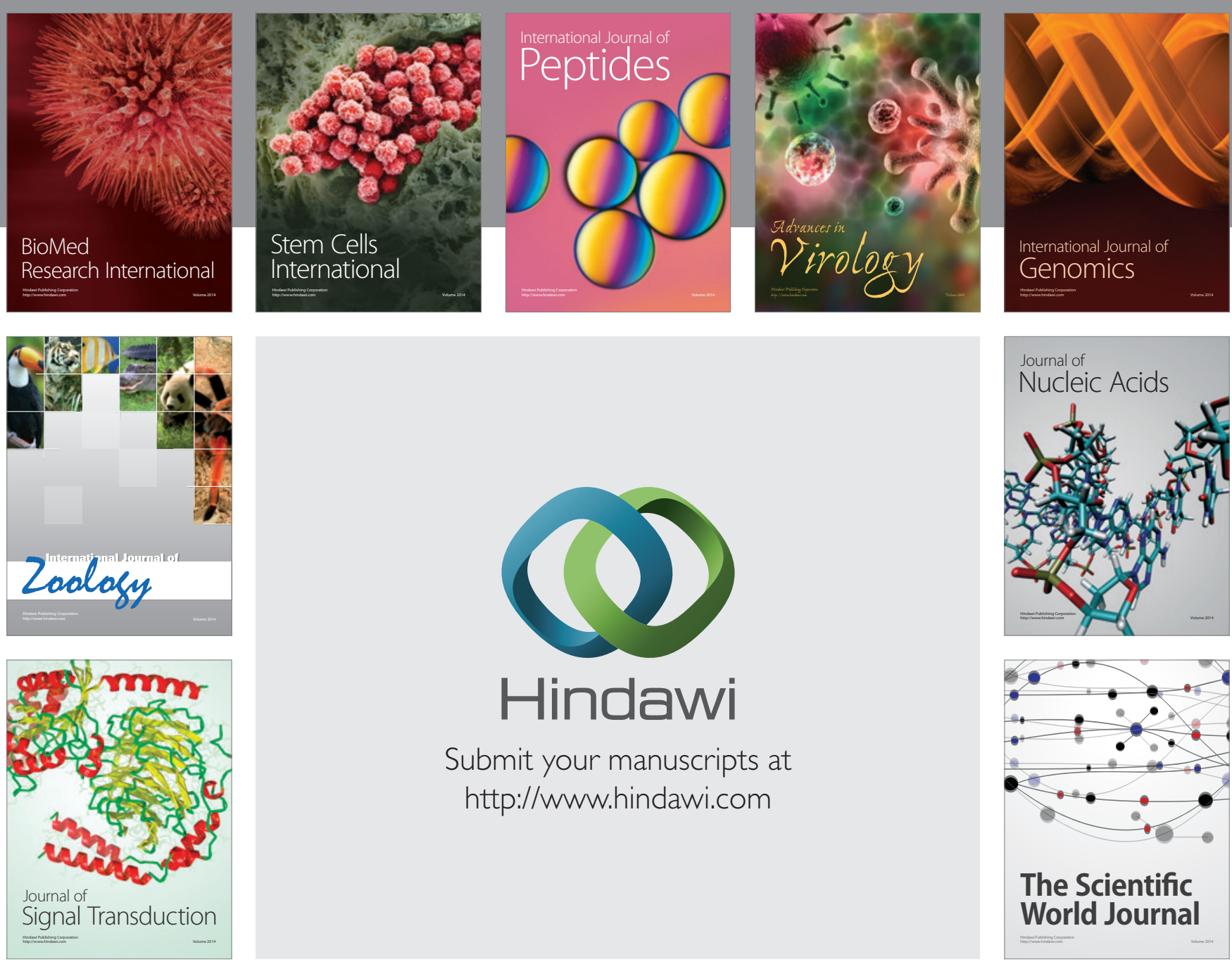

Submit your manuscripts at

http://www.hindawi.com
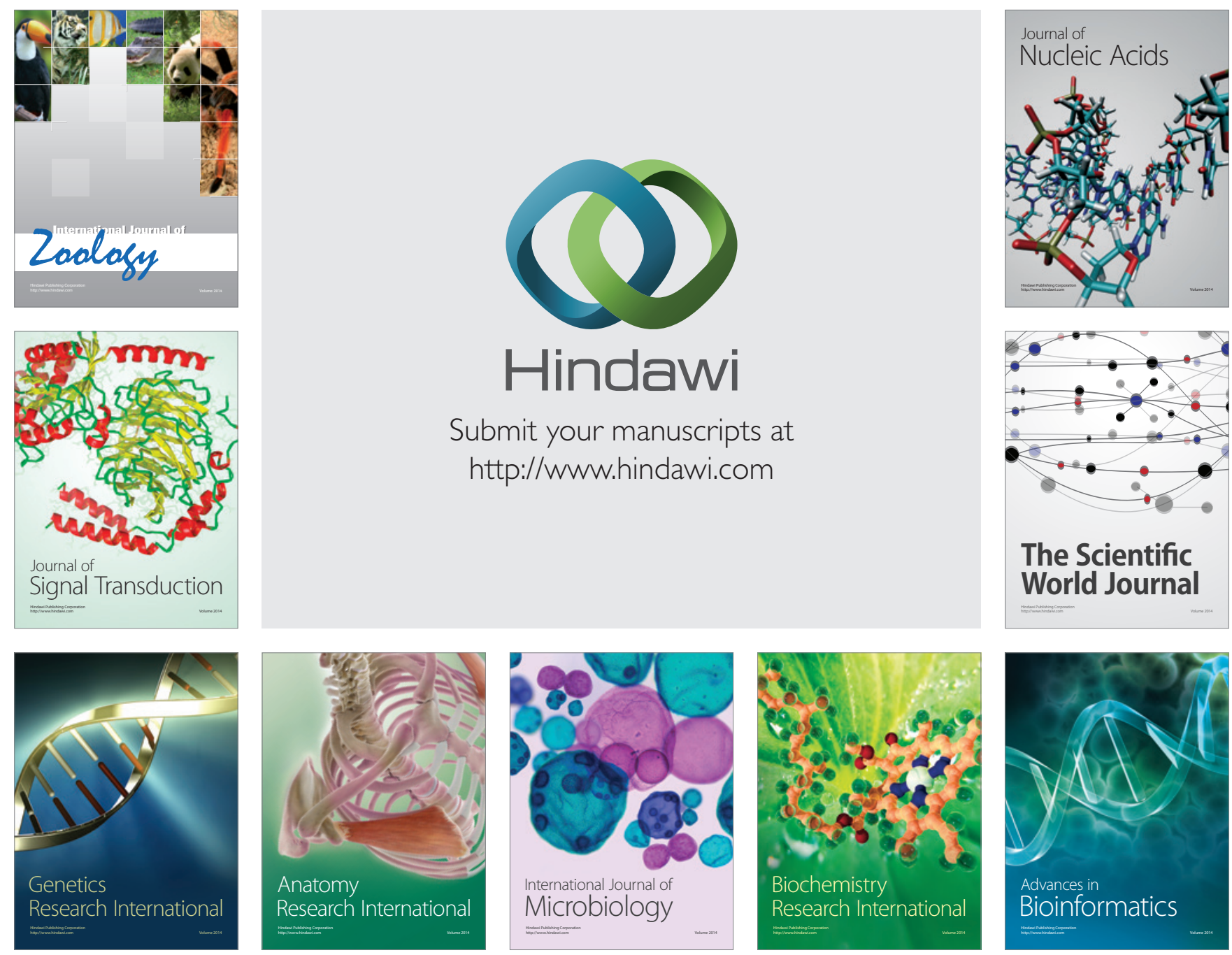

The Scientific World Journal
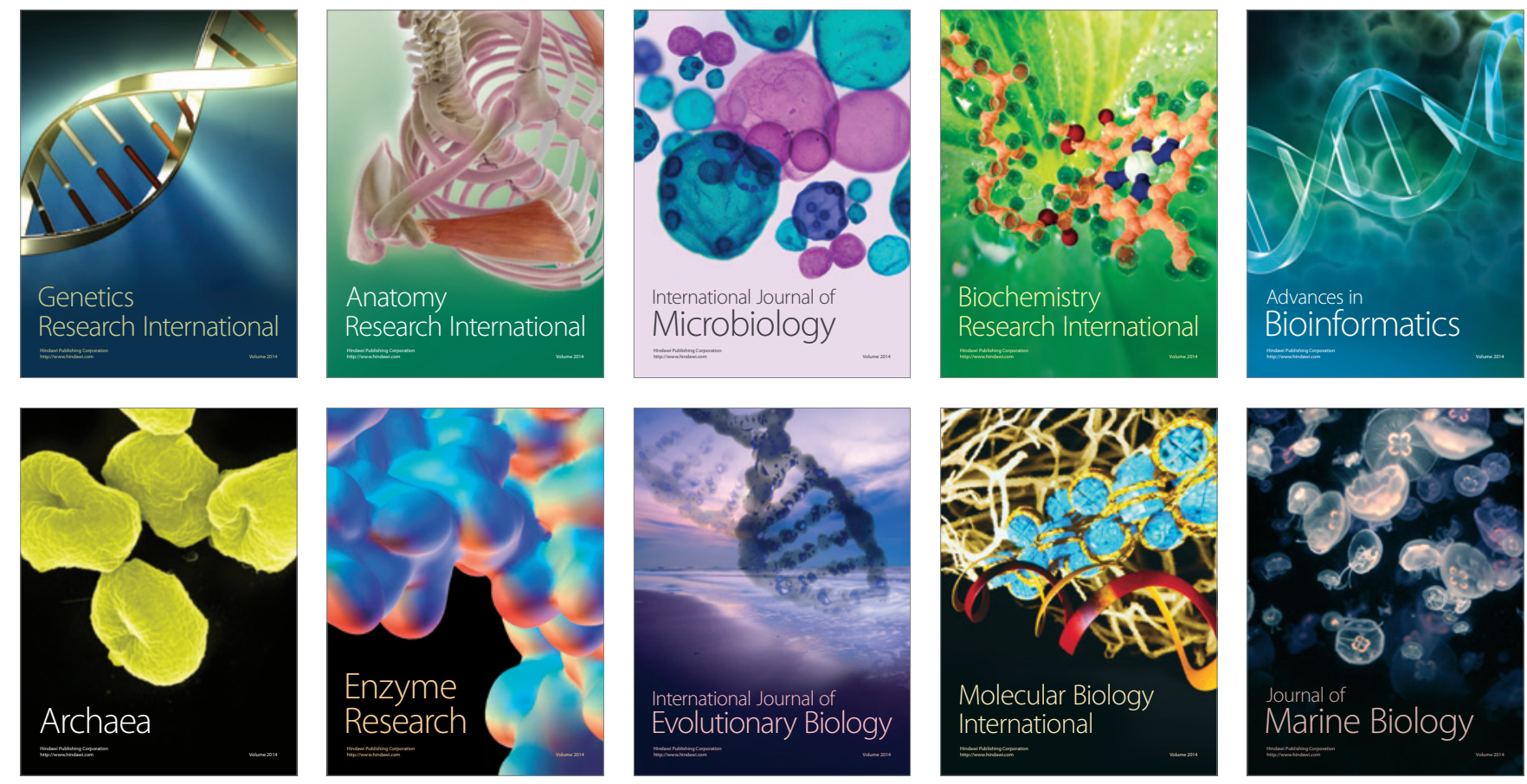